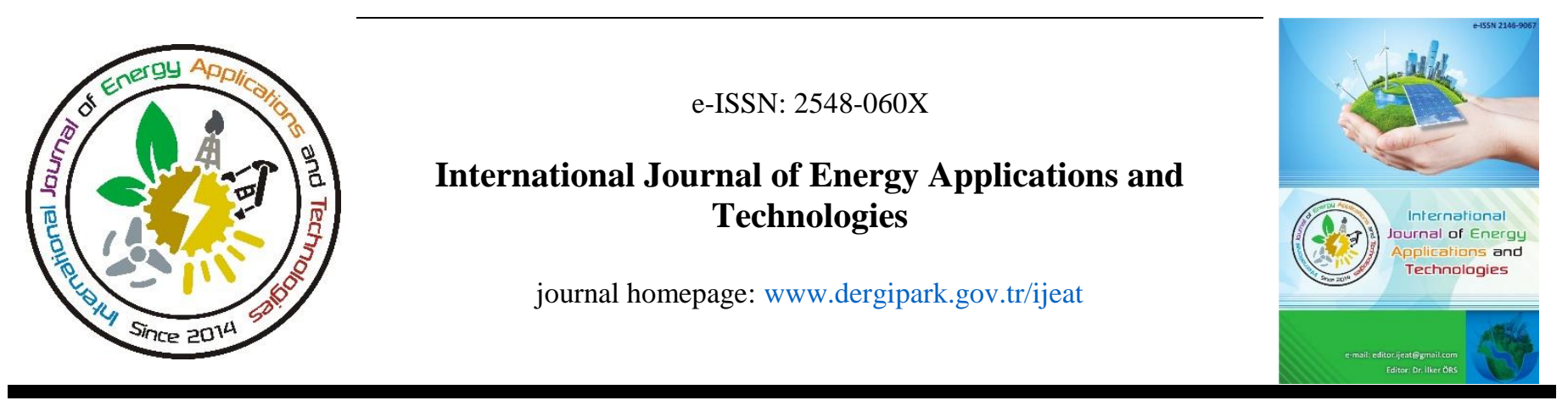

Original Research Article

\title{
Obtaining biodiesel from the enzymatic reaction of bioethanol and crude palm oil which is a fermentation product of corn cob with microorganisms, and the extraction of bioactive substances from the physical refining of biodiesel
}

hosted by Jourkishall Park

\author{
Ufuk Sancar Vural ${ }^{*}$ \\ Seda Kauçuk, Plastik, Maden, Kimya, Enerji İhr.Ith. San. Tic. Ltd. Şti., Afyonkarahisar, Turkey
}

\author{
ARTICLE INFO \\ * Corresponding author \\ usvural@gmail.com \\ Received April 23, 2020 \\ Accepted April 29, 2020 \\ Published by Editorial Board \\ Members of IJEAT \\ (C) This article is distributed by \\ Turk Journal Park System under \\ the CC 4.0 terms and conditions.
}

doi: 10.31593/ijeat.926635

\begin{abstract}
Bioethanol was obtained from the enzymatic hydrolysis of corn cob and then fermentation with microorganisms (yeast). With the bioethanol obtained, biodiesel was obtained from crude palm oil (CPO) by enzymatic method. Bioactive substances were extracted from the phase rich in bioactive substances separated by saponification of CPO and from the sediment obtained from the physical refining of biodiesel.
\end{abstract}

\section{Introduction}

Bioethanol: Although bioethanol production from agricultural wastes is more challenging than molasses, it has started to gain importance in terms of bioethanol production from renewable sources. Corn is one of the most important agricultural products [1]. Corn cobs constitute 30\% of agricultural waste in corn cultivation [2]. Therefore, corn cobs can be used as a renewable raw material source in bioethanol production. Bioethanol production trials were carried out by subjecting corn cob to hydrolysis and then fertilization steps with enzymes obtained from various microorganisms [3-5]. This work aimed at producing bioethanol from corncobs in a batch simultaneous saccharification and fermentation. Aspergillus niger isolated from soil samples from Ejura farms was used to hydrolyze corncobs into simple sugars. Saccharomyces cerevisae was used to ferment the simple sugars into ethanol.
Biodiesel: It meets $85 \%$ of the world's energy demand from petroleum [6]. The fact that oil resources are very limited and their increasing costs are driving scientists to search for new energy sources every day [7]. Biodiesel is a non-toxic, environmentally friendly renewable energy type that does not contain sulfur and aromatic compounds, obtained by the transesterification reaction of vegetable oils with alkyl alcohols and separation of glycerin from fat molecules [8,9]. Converting vegetable oils to biodiesel with the help of biocatalysts (enzymes) attracts great attention due to its high efficiency and purer products [10]. Biodiesel, which is a renewable energy obtained from vegetable oils, is used worldwide by blending it with petroleum based fuels, and its commercial value has gained importance [8].

In this study, biodiesel was produced from palm oil by enzymatic method using bioethanol obtained from corn cobs. Bioactive Compounds: Edible refined palm oil (RPO) is obtained from physical refining of crude palm oil (CPO). 
Palm fatty acid distillate (PFAD) is one of the by-products obtained during the physical refining of crude palm oil. PFAD contains small amounts of bioactive compounds such as glycerides, free fatty acids, tocopherols, tocotrienols, phytosterols, squalene, which are very important for living organisms [11]. PFAD is often used in the soap, animal feed, oleochemistry and biodiesel industries [12-15, 16]. Physical refining of palm oil consists of bleaching and deodorization. These bioactive substances of great importance can be obtained from the physical refining of crude oils or from the fatty acids of these oils. The main component of PFAD consists of $96 \%$ free fatty acids, while the remainder consists of low amounts of bioactive compounds such as glycerides, tocopherols and tocotrienols, phytosterols, squalene and other hydrocarbons $(17,18]$. The bioactive components of PFAD and CPO are collected in the non-saponifiable fraction (USF) [19, 20, 21]. The USF can be separated from the saponifiable fraction by simple saponification. During saponification, the unsaponifiable fraction containing bioactive compounds and the saponification fraction rich in free fatty acids or soap are formed $[19,20]$. USF, obtained by fractionation of PFAD, contains $4.05 \%$ tocopherol, $8.04 \%$ tocotrienol [22, 23] and phytosterol [24]. Purification of USF yields rich fractions with a vitamin E concentration (34\%) and a phytosterol concentration of $17 \%$ [24, 25]. Besides rice bran oil, palm oil has a high tocotrienol content [26, 27]. Tocotrienol is an essential compound in pharmaceuticals, foods, and food supplements. Tocotrienols are very important bioactive compounds and have hypocholesterolemic, antioxidant, antithrombotic, antiatherogenic, antiinflammatory and immunomodulatory properties. It is known that tocotrienols have the ability to lower LDL cholesterol levels. Phytosterols reduce blood cholesterol levels by inhibiting the absorption of cholesterol [28-31]. In addition to increasing breast milk production, phytosterols have anti-inflammation, anti-cancer, immunomodulatory [32], antithrombotic and hypocholesterolemic properties [33-39].

In this study, it was investigated to obtain bio-negative substances during the physical refining of biodiesel obtained from palm oil.

Aim of in this study, bioactive substances such as sterols and vitamin $\mathrm{E}$ were obtained from substances that are very important for energy production from natural resources and for living things. Bioactive substances were also obtained from the sediment obtained from bioethanol, palm oil and bioethanol from corn cobs and biodiesel refining.

\section{Materials and Methods}

\subsection{Bioethanol from corncob}

Sample preparation: The sample (corn cob) was sun dried and micronized to $60 \mu \mathrm{m}$ in a laboratory hammer mill. The corn cobs in powder form obtained were dried at $70^{\circ} \mathrm{C}$ for 4 hours in oven and stored at room temperature.

Pretreatment: $100 \mathrm{~g}$ powder sample was put into two different $1000 \mathrm{~cm} 3$ volume balloons. $1000 \mathrm{~cm} 3$ of $5 \%$ $\mathrm{H} 2 \mathrm{SO} 4$ was added to each flask and the balloon was wrapped in aluminum foil. The sample was drained to remove the oil extracts and the remaining residue was washed using distilled water.

Potatos dextrose agar (PDA): $50 \mathrm{~g}$ of potato dextrose agar powder was dissolved in 1 litre of distilled water in conical flask. It was shaken to dissolve properly and heated with hot plate; the mixture was prepared at $120^{\circ} \mathrm{C}$ for $15 \mathrm{~min}$.

Isolation of Aspergillums Niger: The ground powder of the field soil was collected using a sterilized spatula and transferred to a sterilized sample cup. A sample suspension was prepared by adding $2.0 \mathrm{~g}$ of sample to $20 \mathrm{ml}$ of distilled water and mixed thoroughly for 10 minutes. The suspension was diluted in a ratio of 10: 1, 10: 2 and 10:3. $1 \mathrm{ml}$ (from the third dilution factor) was measured using a syringe and inoculated into a Potato Dextrose Agar (PDA), a glass spreader was used to spread and incubated for the colony for 5 days in an incubation chamber at $280^{\circ} \mathrm{C}$.

Isolation of Zymomonas mobilis: The isolation of Zymomonas mobilis was made from Roselle water performed by the method described by [40]. To obtain roselle juice, the plant was washed and boiled. The water obtained was diluted in a ratio of 10: 1-10: $5.0 .1 \mathrm{ml}$ of the third dilution factor was taken and inoculated into nutrient agar medium using the smear plate method. Plates were incubated in an incubator at $37^{\circ} \mathrm{C}$ for 24 hours. Colonies suspected of being Zymomonas mobilis were characterized according to morphological and biochemical features. Isolates were streaked purified on freshly prepared medium and incubated at $37^{\circ} \mathrm{C}$ for 24 hours. The ability of Zymomonas mobilis to ferment various carbohydrates using glucose, fructose, sucrose, maltose and lactose was determined by growing isolates in liquid standard media (glucose soup) containing $1 \%(\mathrm{w} / \mathrm{v})$ of a specific carbohydrate.

Re-activation of Bake's yeast (Saccharomyces cerevisiae): 1 $\mathrm{g}$ of baker's yeast was directly inoculated into a test tube containing glucose broth, it was allowed to dissolve. It was then inoculated unto the already prepared plates by streaking and then the plates were incubated for 5 days to obtain colony of Saccharomyces cerevisiae.

Enzymatic hydrolysis: The pre-treated sample is used in enzymatic hydrolysis. The pretreated $10 \mathrm{~g}$ sample was poured into twenty different $250 \mathrm{ml}$ conical flasks containing $100 \mathrm{ml}$ of distilled water, the $\mathrm{pH}$ was adjusted in triplicate, the samples were adjusted to $\mathrm{pH}$ 6,7,8 using potassium hydroxide $(\mathrm{KOH})$ and Salicylic acid, and the two samples were at normal $\mathrm{pH}$ It was left in the 's. Each will act as an independent control for a different fermentation. Samples 
were labeled as sample A (10 samples; pH 6, 7, 8 and 3 of 1 control) and sample B (10 samples; $\mathrm{pH} 6,7,8$ and 3 of 1 control). The samples were sterilized at $120{ }^{\circ} \mathrm{C}$ for 15 minutes, then the flasks were allowed to cool and then inoculated with Aspergillums Niger, covered with cotton wool and wrapped in aluminum foil and incubated for five days at $37^{\circ} \mathrm{C}$,

Fermentation of sample by Saccharomyces cerevisiae (Bake's yeast): The fermentation of the samples was carried out according to the methods described by [41]. The hydrolyzates in $250 \mathrm{ml}$ conical flasks were inoculated aseptically with Saccharomyces cerevisiae (Baker's yeast); the flasks were then covered with cotton wool, and wrapped with aluminum foil. The flasks were incubated anaerobically at $35^{\circ} \mathrm{C}$ for 5 days.

Fractional distillation: The fermented samples in $250 \mathrm{ml}$ conical flasks were placed on a heating mantle fixed to a distillation column connected to a cooling condenser from the above. Another set of conical flasks were fixed to the other end of the distillation column to collect the distillate (bioethanol). A heating mantle with the temperature adjusted to $78^{\circ} \mathrm{C}$ as the standard temperature for ethanol production was used to heat the round-bottom flask containing the fermented samples for a period of $40 \mathrm{~min}$ to give room for comparison.

Determination of bioethanol quantity produced: The distillate collected over a slow heat at $78^{\circ} \mathrm{C}$ (for a period of 40 min.), was measured using a measuring cylinder, and expressed as the quantity of ethanol produced in $\mathrm{g} / \mathrm{l}$ by multiplying the volume of distillate collected at $78^{\circ} \mathrm{C}$ by the density of ethanol $(0.80 \mathrm{~g} / \mathrm{ml})$. The $\mathrm{g} / \mathrm{l}$ is equivalent to the yield of $100 \mathrm{~g}$ of the dried.

\subsection{The synthesis biodiesel from crude palm oil (CPO) using immobilized lipase enzyme as catalyst}

Biocatalyst and Chemicals in Transesterification: Lipase Thermomyces lanuginosus immobilised on silica gel (lipozyme RM IM) with catalytic activity of 170 IUN/gl was purchased from Novozymes (Bagsvaerd, Denmark); $170 \mathrm{IUN}$ is defined as $170 \mathrm{mmol}$ of enzyme converting $0.01 \%$ tristearin/min under standard assay conditions. The CPO was obtained from locally from an oil palm industry. Analytical grade methanol in $99.0 \%$ purity were obtained from Merck,

Crude Palm Oil Transesterification: The pretreatment process on CPO was carried out to decant the impurities and the gummy residue that were present. CPO was first centrifuged at a centrifugal rate (RCF) of $3900 \mathrm{rpm}$ at $32^{\circ} \mathrm{C}$ for $6 \mathrm{~min}$, and two layers of liquid and solid phases were formed. The supernatant of CPO was collected as a triglyceride substrate, while the residue solid content was decanted. The transesterification process was initiated at optimum mixture blends of $0.4,0.1$ and 0.5 proportions for CPO, methanol and bioethanol, respectively. Lipozyme RM IM with a range of $2.5-10.0 \%$ wt lipase as per the factorial design matrix was used to initiate the transesterification reaction. A total volume of $30 \mathrm{ml}$ of reaction mixture contained in a $100 \mathrm{ml}$ conical flask was incubated in a water bath shaker at the designated agitation speed (120-200 rpm) so as to investigate the extent of mixing intensity. The agitation speeds used were $\pm 5 \%$ deviation from the actual stirring speed. For statistical evaluation, $50 \mu \mathrm{l}$ aliquots of the sample were withdrawn at 5,10,20 and 30 min for the initial reaction rate determination, and the sampling time was extended to 2, 4 and $6 \mathrm{~h}$ to detect the equilibrium yield of biodiesel. The product achieved at various process conditions was analysed by gas chromatography. Each experimental run was performed in duplicate, and the results were expressed as mean values \pm standard deviations. The standard deviation for biodiesel was $\pm 5 \%$ of the mean value.

\subsection{Extraction of vitamin $E$, phytosterols and squalene}

The methyl esters were separated from glycerol and neutralized by water washing. Methyl esters were subjected to the first short path distillation at temperature of $90^{\circ} \mathrm{C}$. and pressure of 20 mbar. The residue was then subjected to second short path distillation under operating temperature of $150^{\circ} \mathrm{C}$. and pressure of 1 mbar to remove all coloured materials/pigments. The light yellowish distillate was subsequently subjected to third short path dis tillation with temperature of $90^{\circ} \mathrm{C}$. and pressure of 1 mbar for the production of vitamin $\mathrm{E}$, phytosterols and squalene (phytonutrients) concentrates.

(i) first stage short path distillation carried out on the methyl esters obtained by the conversion of crude palm oil into palm oil methyl esters at a temperature of $70^{\circ} \mathrm{C}$ to $120^{\circ} \mathrm{C}$ and pressure between 10 mbar to 50 mbar;

(ii) second stage short path distillation carried out on the residue obtained in step (i) at a temperature of $130^{\circ} \mathrm{C}$ to $200^{\circ} \mathrm{C}$ and pressure less than 1 mbar;

(iii) third stage short path distillation carried out on the distillate obtained in step (ii) at a temperature below $120^{\circ} \mathrm{C}$ and pressure less than 1 mbar;

(iv) saponification of the residue obtained in step (iii) carried out using potassium hydroxide or sodium hydroxide at $10 \%$ concentration and refluxed in alcohol for 30 minutes to one hour under nitrogen blanketing;

(v) mixing the unsaponifiable material in step (iv) with hydrocarbon solvent, short chain $\mathrm{C} 1$ to $\mathrm{C} 4$ alcohol and water of ratio $25: 1: 1$ and heating mixture to temperature of $65^{\circ} \mathrm{C}$ to $85^{\circ} \mathrm{C}$ and cooling slowly to temperature of $25^{\circ} \mathrm{C}$ to $30^{\circ} \mathrm{C}$ to crystallize phytosterols;

(vi) mixing filtrate obtained in step (v) with a hydrocarbon selected from the group consisting of heptane, hexane or iso- 
octane and a short chain $\mathrm{C} 1$ to $\mathrm{C} 4$ alcohol selected from the group consisting of methanol, ethanol, butanol or isopropanol in ratio 5:3 to partition non-polar squalene into hydrocarbon layer and polar vitamin $\mathrm{E}$ into alcohol layer;

(vii) separating two layers and subsequently adding hydrocarbon selected in step (vi) into the alcohol layer and short chain $\mathrm{C} 1$ to $\mathrm{C} 4$ alcohol selected in step (vi) into the hydrocarbon layer to further partition the vitamin $\mathrm{E}$ and squalene and

(viii) extracting squalene from the hydrocarbon layer and extracting vitamin $\mathrm{E}$ from the alcohol layer.

Stage $1.10 \mathrm{~kg}$ of crude palm oil was esterified with $5 \mathrm{~kg}$ of methanol and $500 \mathrm{~g}$ of $\mathrm{NaOH}$ as catalyst. The methyl esters were separated from glycerol and neutralized by water washing. Methyl esters were subjected to the first short path distillation at temperature of $90^{\circ} \mathrm{C}$. and pressure of $20 \mathrm{mbar}$. The residue was then subjected to second short path distillation under operating temperature of $150^{\circ} \mathrm{C}$ and pressure of 1 mbar to remove all colored materials/pigments. The light yellowish distillate was subsequently subjected to third short path distillation with temperature of $90^{\circ} \mathrm{C}$. and pressure of 1 mbar for the production of vitamin $\mathrm{E}$, phytosterols and squalene (phytonutrients) concentrates.

Stage 2. 3 grams of the purified phytonutrients concentrates as obtained from Example 1 or from other sources was saponified using $5 \mathrm{ml}$ of $10 \% \mathrm{KOH}$ and $20 \mathrm{ml}$ of ethanol. The mixture was refluxed under nitrogen blanketing for 30 minutes. The reacted mixture was transferred into a separating funnel with $10 \mathrm{ml}$ of ethanol, $20 \mathrm{ml}$ of hot distilled water and $30 \mathrm{ml}$ of hexane. The mixture was shaken and cooled to room temperature leaving hexane layer at the top and aqueous layer at the bottom. The unsaponifiable materials, which is hexane soluble was collected from the top whereas the aqueous layer was further extracted 5 times with $30 \mathrm{ml}$ hexane water of ratio 9:1. The hexane layer recovered was neutralized with water washing and all the solvents was removed by rotary-evaporator and vacuum pump drying. Recovery of vitamin E. phytosterols and squalene are $84 \%$, $94 \%$ and $87 \%$.

Stage 3. 0.4 grams of the unsaponifiable materials from saponification of purified phytonutrients concentrates as obtained from Example 2 or from other sources was added with $5 \mathrm{ml}$ of ethanol, $5 \mathrm{ml}$ of hexane and $0.5 \mathrm{ml}$ of distilled water. The mixture was shaken to a homogeneous stage and settled into two layers. The hexane layer at the top was separated from the ethanol/water layer at the bottom. Solvents were removed using rotary-evaporator and vacuum pump dryer. The con centration of squalene in hexane layer is $42 \%$ with recovery of $96 \%$ and the concentration of sterols in ethanol layer is $65 \%$ with recovery of $53 \%$. The concentration of vitamin $\mathrm{E}$ in hexane and ethanol layers is $12 \%$ and $20 \%$.

\section{Result and Discussion}

Bioethanol from Corn Cob: The result shows that, the reducing sugar concentration was $0.16 \mathrm{mg} / \mathrm{ml}$, low concentration of bioethanol was $0.33 \mathrm{mg} / \mathrm{L}$. Bioethanol production was studied based on the process of hydrolysis using Aspergillums Niger and fermentative production of ethanol using saccharomyces cerevisiae. Enzymatic hydrolysis is the main step in biomass to ethanol conversion. In this study a fungal culture Aspergillums Niger was used as source of cellulose enzymes in hydrolysis, step which hydrolysis complex cellulosic substrate by the release of extracellular cellulose enzymes and release reducing sugars. The volume of bioethanol produced from corn cobs using saccharomyces cerevisiae at 5 days of fermentation was 29 $\mathrm{g} / \mathrm{l}$ higher than the volume of bioethanol obtained from other plants biomass [32,32]. such as sawdust (12.3 g/l), pineapple $(26.3 \mathrm{~g} / \mathrm{l})$ rice husk $(6.1 \mathrm{~g} / \mathrm{l})$ and empty fruit branches of palm tree $(10.4 \mathrm{~g} / \mathrm{l})$. The differences in volume of bioethanol obtained from different biomass could be associated with the major composition of various feed stocks in addition to fermenting organisms involved in the production process Biodiesel from $C P O$ : This research was conducted by using Crude Palm Oil (CPO) as raw material that had been degumming. Degumming is a separation process gum that consists of phospholipids, protein, residue, carbohydrate, water and resin. The content of Free Fatty Acid (FFA) content in CPO before and after degumming process is shown in Figure 1.

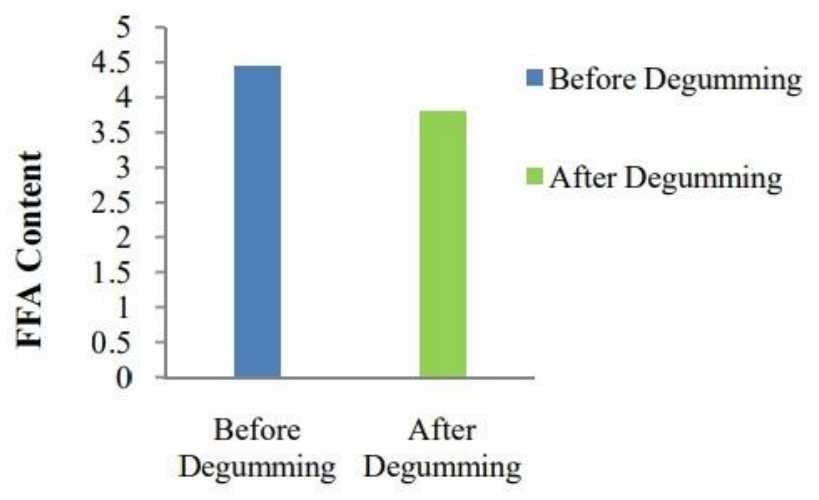

Fig. 1. Analysis of FFA content in CPO before and after degumming Figure 1 indicates that there is decreasing FFA of CPO after degumming for $14 \%$. The decreasing of FFA content means the increasing of enzyme performance as a consequence for the decreasing of content and number of pollutant such as gum that could block the porous and active side of enzyme. Previously, there is an introduction study using CPO as raw material without degumming and the biodiesel yield is $16 \%$, in which this yield is smaller than using degumming CPO as raw material. Based on this condition, the degumming process must be conducted as a pretreatment in using CPO as biodiesel raw material in enzymatic process. On vegetable oil 
and fat, saturated fatty acid is found on external position of sn- 1 and sn- 3 and unsaturated fatty acid on inner side of sn2 (Figure 2).

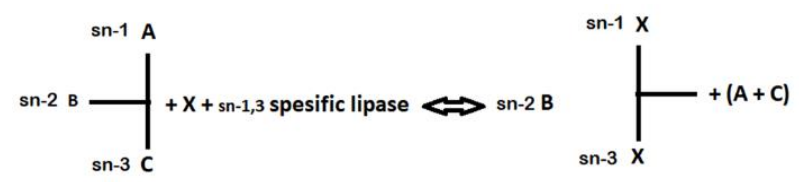

Fig. 2. Interesterification Reaction of Triacylglycerol using Lipase sn1,3 Spesific (A,B, C, X = fatty acid/acyl group)

CPO transesterification at room temperature operation is feasible because the process gave a reasonable biodiesel yield of more than $80 \%$ and an initial reaction rate of $86 \%$ biodiesel yield/h. Among the independent variables, enzyme loading was the most influential process parameter for responses like biodiesel yield and initial reaction rate when the transesterification was operated at $30^{\circ} \mathrm{C}$. The failure of the reaction at $30^{\circ} \mathrm{C}$ to attain a high equilibrium biodiesel yield of $96 \%$, as was observed at $40^{\circ} \mathrm{C}$, was mainly attributed to the heavy viscosity of the reaction mixture, which was temperature dependent. The enzyme denaturation constant at $40^{\circ} \mathrm{C}$ was 1.8 -fold greater than at $30^{\circ} \mathrm{C}$, but the low yield due to enzyme instability was circumvented by the high production rate observed at $40{ }^{\circ} \mathrm{C}$. Besides, the thermal effect at $40{ }^{\circ} \mathrm{C}$ that caused the enzyme to denature was only pronounced after the reaction mixture and the lipozyme RM IM were preincubated at $40{ }^{\circ} \mathrm{C}$ for at least 1 day prior to the transesterification reaction. For the lipozyme RM IM used in the study, $40{ }^{\circ} \mathrm{C}$ was defined as the optimum temperature, resulting in a $96 \%$ biodiesel yield and a moderate enzyme deactivation rate.

In this research, it use immobilized lipase enzyme using support of porous ion exchange resin (Lipozyme RM IM). Lipozyme RM IM is a biocatalyst in specificity sn-1,3 that release the fatty acid from position 1 and 3 of glycerida. By using lipase specific sn-1,3 on interesterification reaction, exchange a half of acyl group is focus to sn-1 and sn-3 positions that increase the product by characteristic that did not found from interesterification chemically. Based on composition of saturated and unsaturated fatty acid in CPO, it is possible that did not less than $39 \%$ fatty acid will conversed to be ester using Lipozyme. Because the dominant fatty acid in CPO is unsaturated fatty acid for $61 \%$ in sn-2 position, the using of non specific enzyme could produces a best yield. The below is a result of density and viscosity analysis of biodiesel as shown in Table 1 .

The result of density and viscosity analysis is suitable to SNI standard, i.e. for density is in rage of $0.84-0.89 \mathrm{~g} / \mathrm{ml}$ in temperature $40^{\circ} \mathrm{C}$ while for kinematic viscosity is in range of 2.3-6.0 cSt in temperature of $40^{\circ} \mathrm{C}$.

Table 1. The result of physical characteristic of biodiesel

\begin{tabular}{ccccc}
\hline $\begin{array}{c}\text { Amount of } \\
\text { Biocatalyst } \\
(\mathbf{b} / \mathbf{b})\end{array}$ & $\begin{array}{c}\text { Molar } \\
\text { Ratio } \\
\text { of } \\
\text { Reactan }\end{array}$ & $\begin{array}{c}\text { Temperature } \\
\left({ }^{\circ} \mathbf{C}\right)\end{array}$ & $\begin{array}{c}\text { Density } \\
(\mathbf{g} / \mathbf{m l})\end{array}$ & $\begin{array}{c}\text { Kinematic } \\
\text { Viscosity } \\
(\mathbf{c S t})\end{array}$ \\
\hline $30 \%$ & $1: 6$ & 50 & 0.87 & 3.52 \\
\hline
\end{tabular}

Extraction of Palm Vitamin, Phytosterols and Squalene from Palm Oil: This study relates to an Integrated process for the recovery of valuable palm oil phytonutrients more particularly vitamin E, phytosterols and squalene which comprises the steps of acid/alkaline catalyzed esterification/transesterification process of palm oil with lower alkyl alcohol, multi-stage vacuum distillation of alkyl esters, saponification of the phytonutrients concentrate, crystallization of phytosterols and finally partitioning of vitamin E and squalene with organic solvents. Extraction of palm vitamin, phytosterols and squalene from palm oil was shown in Figure 3. All results are given in Tables 2-4.

Crude palm oil was esterified in bioethanol using sodium hydroxide as catalyst to substitute the glycerol portion of glycerides with alkyl groups for the production of alkyl esters and glycerol. The type of alkyl alcohols used depending on the volatility of the alkyl esters produced in which the lower boiling point alkyl esters with shorter alkyl chain length are preferable in this case.

The lower boiling alkyl esters were subjected to multi-stage vacuum distillation, preferably three stage short path distillation (SPD) at different operating conditions as described below. The first short path distillation served the purpose to distil about $90 \%$ of the bulk esters with minimal amount of vitamin E, phytosterols and squalene being distilled over to the distillate. The applied short path distillation conditions are temperature ranging from $70^{\circ} \mathrm{C}$ to $120^{\circ} \mathrm{C}$ and pressure ranging from $10 \mathrm{mbar}$ to $50 \mathrm{mbar}$.

Table 2. The phytonutrients concentrates

\begin{tabular}{|l|l|l|l|l|l|l|l|}
\hline \multirow{2}{*}{ Sample } & \multicolumn{5}{|c|}{ Percentage (\%) } \\
\cline { 2 - 8 } & Esters & MG & DG & TG & Squalene & Sterrols & Vitamin E \\
\hline CPO Methyl Esters & 98.20 & 1.10 & 0.23 & 0.06 & 0.07 & 0.06 \\
\hline Residue (1nd Stage) & 84.02 & 9.98 & 2.86 & 0.79 & 0.65 & 0.05 \\
\hline Residue (1nd Stage & 2.44 & 0.00 & 43.58 & 7.81 & 0.00 & 0.06 & 0.63 \\
\hline Residue (1nd Stage & 5.79 & 53.71 & 3.96 & 0.52 & 6.57 & 8.12 & 4.97 \\
\hline Distillate (1nd Stage) & 99.02 & 0.05 & 0.00 & 0.00 & 0.00 & 0.00 \\
\hline Distillate (2nd Stage) & 89.35 & 8.99 & 0.07 & 0.00 & 0.61 & 0.00 & 0.63 \\
\hline Distillate (3nd Stage & 98.43 & 0.22 & 0.00 & 0.00 & 0.00 & 0.02 & 0.00 \\
\hline
\end{tabular}




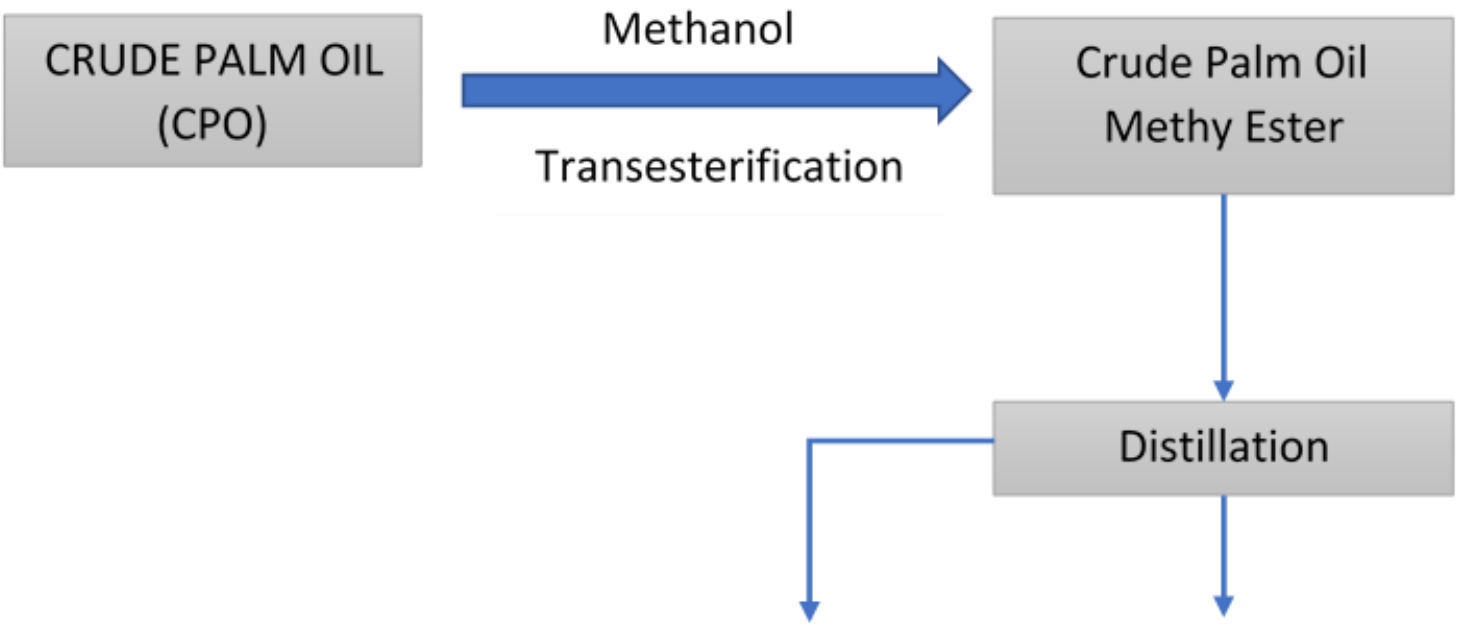

Residue

Distilled Methyl Ester

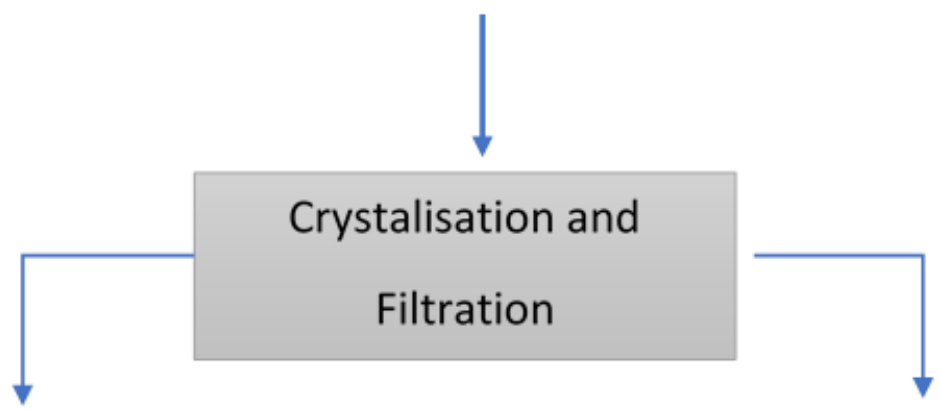

Vitamin E Concentrate

\section{Adsorption, Purification (Tocotrienol Rich Fraction)}

Solid by product

(Physsterol resource, PSR)

Fig 3. Bioactive compounds and biodiesel (CPO methyl ester) pathway

Table 3. The phytonutrients concentrates

\begin{tabular}{|l|l|l|l|l|l|l|l|}
\hline \multirow{2}{*}{ Sample } & \multicolumn{5}{|c|}{ Percentage (\%) } \\
\cline { 2 - 8 } & Esters & MG & DG & TG & Squalene & Sterrols & Vitamin E \\
\hline Purified Pytonntrients & 4.58 & 66.43 & 0.00 & 1.07 & 6.49 & 15.10 \\
\hline Unsaponifiable Materials & 0.0 & 0.00 & 0.00 & 2.5 & 20.5 & 6.78 & 52.30 \\
\hline
\end{tabular}

Table 4. The phytonutrients concentrates

\begin{tabular}{|l|l|l|l|l|l|l|l|}
\hline \multirow{2}{*}{ Sample } & \multicolumn{5}{|c|}{ Percentage (\%) } \\
\cline { 2 - 8 } & Esters & MG & DG & TG & Squalene & Sterrols & Vitamin E \\
\hline Unsaponifiable Materials & 0.00 & 0.00 & 0.00 & 2.90 & 25.40 & 49.55 & 18.30 \\
\hline Hexane Layer & 0.00 & 0.00 & 0.00 & 4.80 & 41.20 & 39.60 & 12.00 \\
\hline Ethanol Layer & 0.00 & 0.00 & 0.00 & 0.30 & 9.40 & 64.30 \\
\hline
\end{tabular}

The phytonutrients enriched residue was then subjected to second short path distillation in the removal of all the impurities and coloring materials/pigments including carotenes, phospholipids, glycolipids, waxes, oxidized products and other long chain hydrocarbons. The operating conditions are temperature ranging from $130^{\circ} \mathrm{C}$ to $200^{\circ} \mathrm{C}$ and pressure less than 1 mbar. The distillate from the second short path distillation was subsequently subjected to the third short path distillation to produce vitamin E, phytosterols, squalene and monoglycerides concentrates in a mixture with operating temperature less than $120^{\circ} \mathrm{C}$ and pressure less than 1 mbar. The purified concentrate is free from all indigenous heavy molecules which is critical in the following separation and purification processes.

To the purified concentrate, saponification process was carried out in the presence of sodium hydroxide and ethanol. They hydroxides used are sodium hydroxide and potassium hydroxide whereas alcohols used including methanol, 
ethanol and iso-propanol. Preferably, the saponification process is carried out using potassium hydroxide or sodium hydroxide at $10 \%$ concentration and refluxed in alcohol for 30 minutes to one hour under inert gas (nitrogen) blanketing. The unsaponifiable materials were recovered using hydrocarbon solvents extraction of the reaction mixture such as heptane, hexane, iso-octane and petroleum ether. The hydrocarbon layer was neutralized with copious of water washing and the unsaponifiable matters recovered containing only vitamin E, phytosterols and squalene.

Phytosterols were crystallized out from the unsaponifiable mixture using water/alcohol/hydrocarbon system by heating and cooling processes preferably from $65^{\circ} \mathrm{C}-85^{\circ} \mathrm{C}$ to $10^{\circ} \mathrm{C}$ $30^{\circ} \mathrm{C}$. The crystallized phytosterols were filtered and to the remaining part of the mixture, hydrocarbon solvent and alkyl alcohol was introduced to partitioning the less polar squalene into hydrocarbon layer and the relatively more polar vitamin E into the alkyl alcohol layer. The alkyl alcohols used including methanol, butanol and iso-propanol and hydrocarbon solvents used including hexane, heptane and iso-octane. Preferably, the unsaponifiable material is mixed with hydrocarbon solvent, short chain $\mathrm{C} 1$ to $\mathrm{C} 4$ alcohol and water of ratio $25: 1: 1$ and heated to temperature of $65^{\circ} \mathrm{C}$ to $80^{\circ} \mathrm{C}$ and slowly cooled to temperature of $10^{\circ} \mathrm{C}$ to $30^{\circ} \mathrm{C}$ to crystallized phytosterols. Further preferred is a method wherein the filtrate is mixed with hydrocarbon solvent and short chain $\mathrm{C} 1$ to $\mathrm{C} 4$ alcohol of ratio 5:3 to partition the nonpolar squalene into hydrocarbon layer and polar vitamin $\mathrm{E}$ into alcohol layer.

\section{Conclusion}

Extraction and purification of phytosterols from solid residue obtained after vitamin E extraction from PFAD have been successfully conducted using multistage extraction processes in laboratory scale. Technically, the multistage extraction and purification methods in laboratory scale which comprised of SLE, saponification reaction, LLE, crystallization and filtration, were capable to produce phytosterols mixture with purity of up to $94 \%$ (w/w) with individual sterols compositions of $\beta$-sitosterol (21\%-22\%), campesterol (13\%-20\%) and stigmasterol (59\%-64\%). The overall recovery for sterol from the PSR was $84 \%$. This extraction process is technically feasible to extract and produce crude phytosterols from a PFAD by-product and the extraction of this minor component will adds value to the oil palm industry.

\section{ORCID}

U. S. Vural 0000-0002-8510-9616

\section{References}

[1] Asante A. 2004. Assessment of food import and food aid against support for agricultural development, the case of Ghana. Draft report for FAO Regional Office, p.10.

[2] Rangkuti M, Djajanegara A. 1983. The utilization of agricultural byproducts and wastes (as animal feeds) in Indonesia. In: The use of organic residues in rural communities animal feeds in South East Asia. Proceedings, Workshop on Organic Residues in Rural Communities. Denpasar (Indonesia), 11 Dec 1979, pp.11-25.

[3] Ohgren, K., Bengtsson, O, Gorwa-Grauslund, M.F., Galbe M, Hahn-Hagerdal B, Zacchi, G.(2006. Simultaneous saccharification and cofermentation of glucose and xylose in steam-pretreated corn stover at high fiber content with Saccharomyces cerevisae TMB3400. J. Biotechnol. 126(4): 488-498.

[4] Cao N.J, Krishnan M.S, Du J.X, Gong C.S, Ho N.W.Y., Chen Z.D, Tsao G.T. 1996. Ethanol production from corn cob pretreated by ammonia steeping process using genetically engineered yeast. Biotechnol. Lett. 18(9): 1013-1018.

[5] Wyman C.E, Spindler D.D, Grohmann K. 1992. Simultaneous saccharification and fermentation of several lignocellulosic feedstocks to fuel ethanol. Biomass Bioenergy, 3(5): 301-307.

[6] Atadashi, I.M. \& Aroua, M.K. \& Aziz, A. Abdul, 2011. Biodiesel separation and purification: A review, Renewable Energy, 36(2), 437-443.

[7] Hossain, A.B.M.S. and Mekhled, M.A. 2010. Biodiesel fuel production from waste canola cooking oil as sustainable energy and environmental recycling process, Aust. J. Crop. Sci. 4, 543-549.

[8] Demirbas,A. 2003. Energy. Biodiesel fuels from vegetable oils via catalytic and non-catalytic supercritical alcohol transesterifications and other methods: a survey, Energy conversion and Management. 44 (13), 2093-2109.

[9] Vicente, G., Martínez, M. And Aracil,J. 2007. Optimisation of integrated biodiesel production. Part I. A study of the biodiesel purity and yield, Bioresource Technology, 98(9), 1724-1733,

[10] Akoh, C.C., Chang S.W. and Lee, J.F. 2007. Shaw, Enzymatic approach to biodiesel production, J. Agric. Food Chem. 55(22), 8995-9005.

[11] Gapoor, A, Hassan, W.H.W., Sulong, M. 2002. Phytochemical for nutraceutical from the by product of palm oil refining. Palm Oil Develop. 36, 13-9.

[12] Nang H.L.L, Wafti N.S.A, May C.Y. 2009. Palm fatty acid distillate. MPOB Information, MPOB No. 471. 
[13] Cheah K.Y, Toh T.S, Koh P.M. 2010. Palm fatty acid distillate biodiesel: next generation palm biodiesel. Inform. Champaign: AOCS..

[14] Deshmane, V.G., Gogate, P.R., Pandit, A.B.. 2009. Ultrasound-assisted synthesis of biodiesel from palm fatty acid distillate. Ind Eng Chem Res. 48,7923-7.

[15] Chabukswar D.D, Kaur H.P, Gaikar V.G.2013. Esterification of palm fatty acid distillate using heterogeneous sulfonated microcrystalline cellulose catalyst and its comparison with $\mathrm{H}_{2} \mathrm{SO}_{4}$ catalyzed reaction. Ind Eng Chem Res. 52, 7316-7326.

[16] Jones, P J H; Ntanios, F Y; Raeini-sarjaz, M and Vanstone, C A 1999. Cholesterol-lowering efficacy of a sitostanol-containing phytosterol mixture with a prudent diet in hyperlipidemic men. Am. J. Clin. Nutr., 69, 1144-1150.

[17] Rakmi, A.R.; Herawan, T. 2000. Properties of biosurfactant enzymatically prepared from fructose and palm fatty acid. J. Oil Palm Res. 12, 117-122.

[18] [18] Gapoor, A., Hassan, W.H.W., and M. Sulong. 2002.. Phytochemical for nutraceutical from the by product of palm oil refining. Palm Oil Development 36. 13-19.

[19] Estiasih T, Mukhlishiyiyah J. 2015. Optimizing saponification condition for unsaponifiable matters preparation from crude palm oil Research Repport of Agricultural Technology Faculty Grant, Brawijaya University Malang

[20] Estiasih T, Ahmadi K, Widyaningsih TD, Maligan JM. 2012. Multi components of bioactive compounds for food supplement and fortificant as an effort to increase economical value of byproduct of palm oil refinery Year 1 MP3EI Report. Research Centre Brawijaya University Malang

[21] Khatoon S, Rajan RGR, Krishna AGG 2010. Physicochemical characteristics and composition of Indian soybean oil deodorizer distillate and the recovery of phytosterols, J. Am. Oil Chem. Soc. 87 321-326.

[22] Ahmadi K,T., Estiasih, T. 2009. Low temperature solvent crystallization in vitamin $\mathrm{E}$ enriched tocotrienols preparation from palm fatty acid distillate and its application for functional foods Year $1 \mathrm{PHB}$ Report, Research Centre, Tribhuwana Tunggadewi University, Malang

[23] Ahmadi K, Estiasih, T. 2010. Low temperature solvent crystallization in vitamin $\mathrm{E}$ enriched tocotrienols preparation from palm fatty acid distillate and its application for functional foods Year 2 PHB Report, Research Centre, Tribhuwana Tunggadewi University, Malang

[24] Ahmadi K, Estiasih T. 2011a. Phytosterols separation from palm fatty acid distillate and its utilization for reducing cholesterol Year 1 PHB Report, Research Centre, Tribhuwana Tunggadewi University, Malang

[25] Ahmadi, K., \& Estiasih, T.. 2011. Kristalısası Pelarut Suhu Rendah Pada Pembuatan Fraksı Kaya Vitamın E Mengandung Tokotrienol Darı Distılat Asam Lemak Minyak Sawit [Low Temperature Solvent Crystallizationin Tocotrienol Containing Vitamin E Rich Fraction Preparation From Palm Fatty Acid D. Jurnal Teknologi Dan Industri Pangan, 22(2), 142.

[26] Ng, M.H., Chao, Y.M., Ma, A.H., Choah, C.H., and Hashim, M.A. 2004. Separation vitamin E, tocotrienol, and tocomonoenal) in palm oil". Lipids 39. 1031-1035.

[27] Puah, C.W., May, C.Y., Ahngan, M., and Hock, C.C. 2004. Degumming and bleaching: Effect on selected constituents of palm oil. Journal of Oil Palm Research 16. 57-63.

[28] Lewis J. 2001 Process for the production of tocotrienol, US Patent 6,838,104

[29] Coskun A.M, Serteser, U, I 2013 Inhibition of cholesterol biosynthesis in hypercholesterolemiaIs it the right choice? J. Med Biochem 32(1) 16-19.

[30] Loganathan, R., Selvaduray, K. R., Radhakrishnan, A., \& Nesaretnam, K. .2009. Palm oil: Rich in health promoting phytonutrients. Palm Oil Developments, 50(1), 16-25.

[31] Taşan, M., Bilgin, B., Geçgel, Ü., Demirci,Ş. 2006. Phytosterols as functional food ingredients. Trakya Univ. J. Tekirdag Agric. Fac., 3:153-159

[32] Awad A.B., Fink C.S.. 2000. Phytosterols as anticancer dietary components: evidence and mechanism of action. J Nutr. 130(9):2127-2130. doi: 10.1093/jn/130.9.2127. PMID: 10958802.

[33] Carr T.P, Ash M.M, Brown A.W.2010. Cholesterol Lowering Phytosterols: Factors Affecting Their Use and Efficacy. Nutr Dietary Suppl. 2, 59-72.

[34] Piironen V., Lindsay, D.G., Mieyyinen, T.A., Toivo, J., and Lampi, A.M. 2000. Plant sterol: biosynthesis, biological function and their importance to human nutrition. J. Sci. Food Agric. 80. 939-966..

[35] Ostlund R.E Jr., McGill J.B., Zeng C.M, Covey D.F, Stearns J, Stenson W.F, Spilburg C.A. 2002a. Gastrointestinal absorption and plasma kinetics of soy Delta(5)-phytosterols and phytostanols in humans. Am J Physiol Endocrinol Metab 282:E, 911-916.

[36] Bonsdorff-Nikander A.V. 2005. Studies on a cholesterol-lowering micro crystalline phytosterol suspension oil Dissertation University of Helsinki, Helsink.

[37] Qureshi A.A, Lehmann J.W, Peterson D.M. 1996. Amaranth and its oil inhibit cholesterol biosynthesis antimicrobial properties of plant essential oils and in 6- 
week-old female chickens. Journal of Nutrition, 126: 1972-1978.

[38] Shin, D.H., Heo, H.J., Lee, Y.J. and Kim, H.K. 2004. Amaranth squalene reducesserum and liver lipid levels in rats fed a cholesterol diet, British Journal of Biomedical Science, 61(1), 11-14.

[39] De Castro, L.Í., Andrade, Soares, R.A., Manólio, Saldiva, P.H.N., Ferrari, R.A., Miguel, A.M.2013. Amaranth oil increased fecal excretion of bile acid but had no effect in reducing plasma cholesterol in hamsters, Lipids. 48 (6). 609-18.

[40] Estiasih T, Ahmadi K, Widyaningsih T.D, Maligan J.M, Mubarok A.Z, Zubaidah E, Mukhlisiyyah J, Puspitasari R. 2013. Bioactive compounds of palm fatty acid distillate (PFAD) from several palm oil refineries. $A d v$. J. Food Sci. Tech. 5(9): 1153-1159.

[41] Ceriani R, and Meirelles A.J.A. 2004 Simulation of continuous deodorizers: effects on product streams, $J$. Am. Oil Chem. Soc. 81, 1059.

[42] Benites C.I., Concha V.O.C., Reis S.M.P.M., de Oliveira A.C.2009. Physiochemical Characterization of Soybean Oil Deodorizer Distillate. Chemical Engineering Transactions., 17, 903-908. 